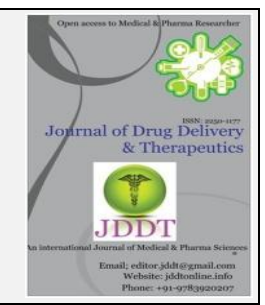

Review Article

\title{
NATURAL PRODUCTS USED AS ANTI-CANCER AGENTS
}

\author{
Mohammad Zishan*1, Saidurrahman ${ }^{2}$, Anayatullah², Azeemuddin ${ }^{2}$, Zeeshan Ahmad ${ }^{1}$, Md \\ Wasim Hussain ${ }^{1}$
}

${ }^{1}$ Department of Pharmaceutics, Faculty of Pharmacy, Integral University, Dasauli, Kursi Road, Lucknow, 226026

${ }^{2}$ Department of Pharmacology, Faculty of Pharmacy, Integral University, Dasauli, Kursi Road, Lucknow, 226026

Article Info: Received 09 April 2017; Review Completed 22 April 2017; Accepted 22 April 2017, Available online 15 May 2017 Cite this article as:

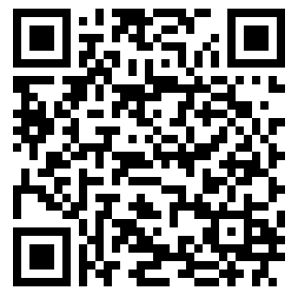

Zishan M, Saidurrahman, Anayatullah, Azeemuddin, Zeeshan A, Hussain MW, Natural products used as anti-cancer agents, Journal of Drug Delivery and Therapeutics. 2017; 7(3):11-18

DOI: http://dx.doi.org/10.22270/jddt.v7i3.1443

*Address for Correspondence

Mohammad Zishan, Research Scholar, Faculty of Pharmacy, Integral University, Dasauli, Kursi Road Lucknow, 226026

E-mail: zishanquadri786@gmail.com

\begin{abstract}
In the present time Natural products are considered to be symbols of protection in comparison to the synthetic product that are regarded as unsafe to human life and environment. Although a large number of synthetic drugs are being added to the world of present pharmacopoeia, but still no system of medicine in the world has been able to solve all the health problems, which include diseases like Cancer. Plant-derived compounds have played an important role in the development of several clinically useful anticancer agents. These include vinblastine, vincristine, the camptothecin derivatives, topotecan and irinotecan, etoposide, derived from epipodophyllotoxin, and paclitaxel (taxol). Several promising new agents are in clinical development based on selective activity against cancer-related molecular targets, including flavopiridol and combretastin A4 phosphate, and some agents which failed in earlier clinical studies are stimulating renewed interest. Therefore the search for innovative therapeutic constituents from plants is genuine and urgent. In India, there is an ocean of knowledge about medicinal plants and rich medicinal flora, but still only a few pearls have been searched as therapeutic agents.
\end{abstract}

Key words: Cancer, Anti-cancer agents, Natural Plant

\section{INTRODUCTION}

Plants have a long history of use in the treatment of cancer. Hartwell, in his review of plants used against cancer, lists more than 3000 plant species that have reportedly been used in the treatment of cancer. The word "Cancer" was coined by a Greek physician Hippocrates (460 - $370 \mathrm{BC}$ ), who is further more well thought-of as the "Father of Medicine". Hippocrates used the terms "carcino" and "carcinoma" to describe non-ulcer forming and ulcer-forming tumors. Galen (130-200 AD), another Roman physician, used the word oncos' (Greek for swelling) to describe tumors. A mature human comprises about 1015 cells; scores of them divide and differentiate in order to renew organs and tissues, which require cell turnover ${ }^{1}$.

Cancer is one of the most common devastating disease affecting millions of people per year. Cancer has been estimated as the second leading cause of death in humans. So there has been an intense search on various biological sources to develop a novel anti-cancer drug to combat this disease. Plants have proved to be an important natural source of anti-cancer therapy for several years. About 30 plant derived compounds have been isolated so far and are currently under clinical trials. These anti-cancer compounds have been found to be clinically active against various types of cancer cells 
2. Among the causes for cancer are tobacco, viral infection, chemicals, radiation, environmental factors, and dietary factors [. Ontogenesis is regulators of cellular communication with the outside environment. They are derived through the mutation of protooncogene. Mutated oncogenes are stimulated by exposure to chemical, environment or viral carcinogens, which leads to cell changes and they produce proteins which are either wrongly expressed within their normal cell or expressed in inappropriate tissue which leads to cellular proliferation and there by result in cancer formation. Tumor suppressor genes are intended to keep oncogenes in check by halting uncontrolled cellular growth. In direct opposition to oncogenes, which induce cancer when stimulated or amplified, tumor suppressor genes promote cancer when inactivated or attenuated. Two of the most prevalent tumor suppressor genes involved in the generation of cancer is p53 and retinoblastoma or $\mathrm{Rb}^{4}$. Cancer is a term that is used to refer to a number of conditions where the body's cells begin to grow and reproduce in an uncontrollable way. This rapid growth of cancerous cells is known as a malignant tumour. These cells can then invade and destroy healthy tissue, including organs ${ }^{5,6}$. Cancer sometimes begins in one part of the body before spreading to other parts. This process is known as metastasis.

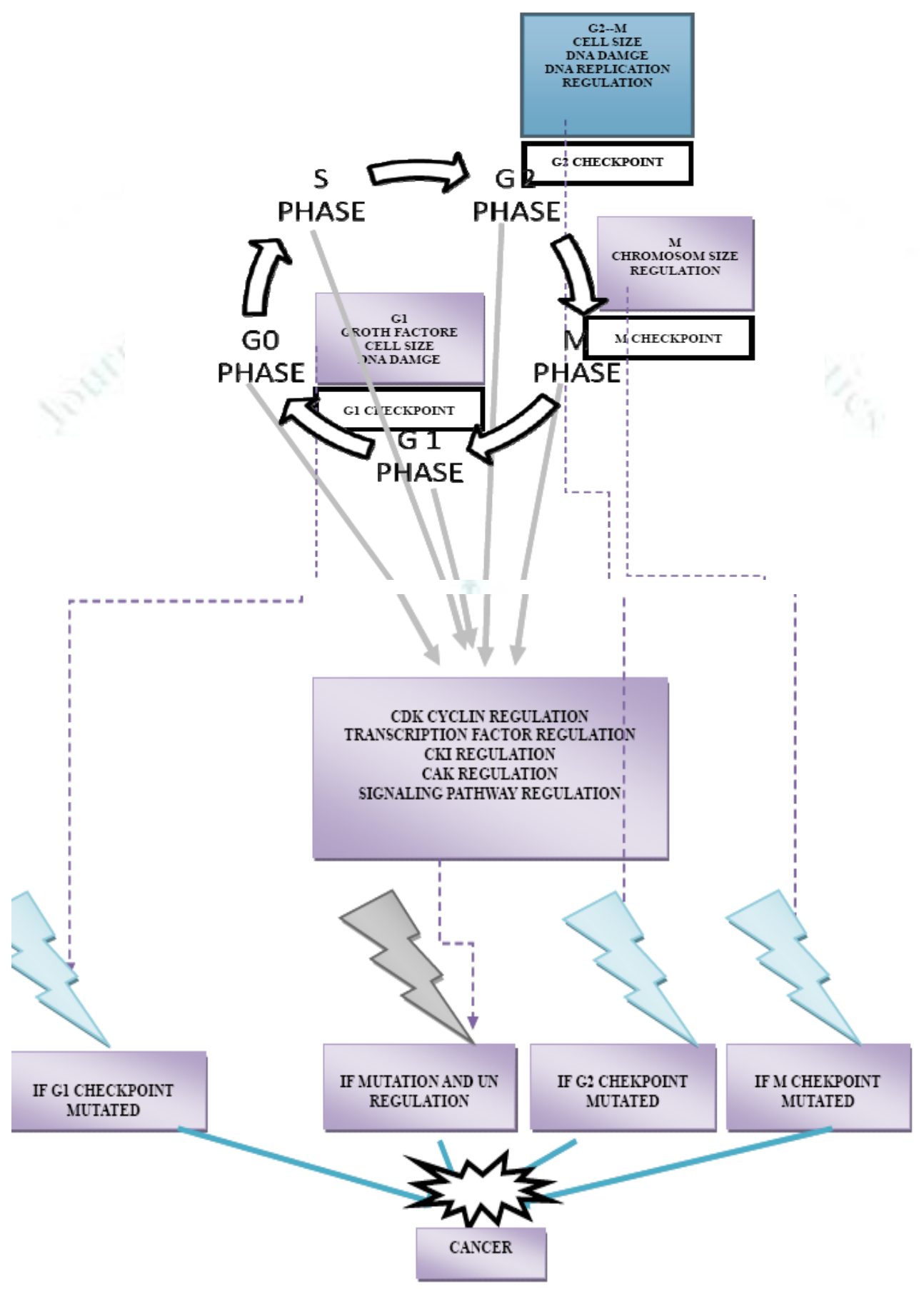

Figure 1. Cancer cell regulation and deregulation mechanism. 


\subsection{How common is cancer?}

Cancer is a common condition and is a serious health problem, both in the UK and across the world. It is estimated that 7.6 million people in the world died of cancer in 2007. In the UK, cancer is responsible for 126,000 deaths per year. One in four people die from cancer ${ }^{7}$.

\subsection{Anti-cancerous drugs under clinical trials}

There are four major structural classifications of plantderived anticancerous compounds viz., Vinca alkaloids, Epipodophyllotoxin lignans, Taxane diterpenoids and Camptothecin quinolone alkaloid derivatives. Different anti-cancer compounds that have been identified and reported by scientists have been reviewed under ${ }^{8}$

\subsection{Types of cancer}

There are hundreds of different types of cancer. The most common cancers in the UK are: Breast cancer, Prostate cancer, Lung cancer, Cancer of colon or rectum, Blood cancer, Bladder cancer, ovarian cancer etc. Risk factors for cancer include smoking, drinking alcohol, obesity, poor diet, lack of exercise, and prolonged exposure to sunlight.

\subsection{Treatments of Cancer}

Treatments of cancer include Surgery, Chemotherapy and Radiotherapy. Some cancers can be cured if detected early enough ${ }^{9}$.

\subsection{Plant-Derived Anti-Cancer Agents in Clinical Use ${ }^{10}$.}

Natural products have anti-cancerous potential due to the occurrence of natural antioxidants carrying out as reducing agents, free radical scavengers and quenchers of singlet oxygen. Greater part of their antioxidant action is due to bioactive compounds viz. flavones, isoflavones, flavonoids, anthocyanins, coumarins, lignans, catechins and isocatechins as well natural products can reduce or minimize the toxic side effect of chemotherapy and radiation treatment by reinforcing their cancer killing ac- tion. Significant assistance has been made by They worked out the cytotoxic activity of medicinal plants and studied their anti-proliferative activity against cancer. In the present time natural products are considered to be symbols of protection in comparison to the synthetic product that are regarded as unsafe to human life and environment that is by natural products had been priced for their medicinal importanc

\subsubsection{Vinca alkaloids}

Vinca alkaloids belong to an important class of anticancer drugs. The mechanism of action of Vinca alkaloids is that they inhibit the cell proliferation by affecting the microtubular dynamics during mitosis, and this causes a characteristic block during mitosis leading to apoptosis. Certain semi-synthetic analogues have been developed to increase the therapeutic index.
Vinblastine (VLB) and Vincristine (VCR) are the two major naturally occurring active compounds obtained from the Madagascar periwinkle, Catharanthus roseus G. Don. (Apocynaceae). These compounds reported potential activity against lymphocytic leukemia in mice. Vinorelbine(VRLB) and Vindesine (VDS) are the two semisynthetic analogs obtained from the active compounds. They showed potential activity against leukemia's, lymphomas, advanced testicular cancer, breast cancer, lung cancer and Kaposi's sarcoma when treated in combination with other chemotherapeutic drugs ${ }^{11}$. Vinca alkaloids are most commonly administered weekly by short IV injection (1-15min), more rarely by continuous infusion. Vinorelbine is the sole alkaloid available orally and it is administered as a single dose weekly ${ }^{12}$. Vinorelbine is used for the treatment of non-small cell lung cancer and metastatic breast cancer. The main toxic effect of vinorelbine is granulocytopenia with only modest thrombocytopenia and less neurotoxicity than other vinca alkaloids ${ }^{13}$. Vinflunine has been used in the treatment of bladder, non-small cell lung and breast cancers; its main side effects are myelosuppression and constipation which are apparently more manageable compared to the other vinca alkaloids ${ }^{14}$.

\subsubsection{Podophyllotoxin}

Podophyllotoxin is obtained from the roots of Podophyllum species, namely, Podophyllum peltatum Linnaeus and Podophyllum emodi Wallich. This was isolated in 1880s, and their structure was elucidated in 1950s. Epipodophyllotoxin is an isomer of podophyllotoxin. The two clinically important semisynthetic analogs generated from Epipodophyllotoxin are Etoposide and Teniposide which were found very potential in treating lymphomas, bronchial and testicular cancers ${ }^{15}$ Podophyllotoxin, an active principle of podophyllin, is used in the treatment of Hodgkin's disease, non-Hodgkin's lymphoma, leukaemia, and cancers of the ovary ${ }^{16}$.

\subsubsection{Taxanes}

Paclitaxel (Taxol®) is obtained from the bark of the Pacific Yew, Taxus brevifolia Nutt. (Taxaceae). Their structure was first identified in the year 1971 and they entered the market since 1990s. Another species, Taxus baccata, an Indian Ayurvedic medicine have also been in use for cancer therapy ${ }^{17}$. Paclitaxel was found poorly water-soluble and toxic, hence, a water soluble compound, Docetaxel was derived. Docetaxel (Taxotere $\AA$ ), a semi-synthetic derivative of paclitaxel was found more effective. Docetaxel can be used in patients who are resistant to paclitaxel. Both docetaxel and paclitaxel are used as first- and secondline treatment in patients suffering from metastatic cancer, breast cancer and ovarian cancer. These drugs are also found active against lung cancer, prostate cancer and also lymphoid malignancies. The mechanism of action is that these active agents bind to the polymerized microtubules which prevent the normal mitosis to occur and thus they are called anti-mitotic drugs ${ }^{18}$. 


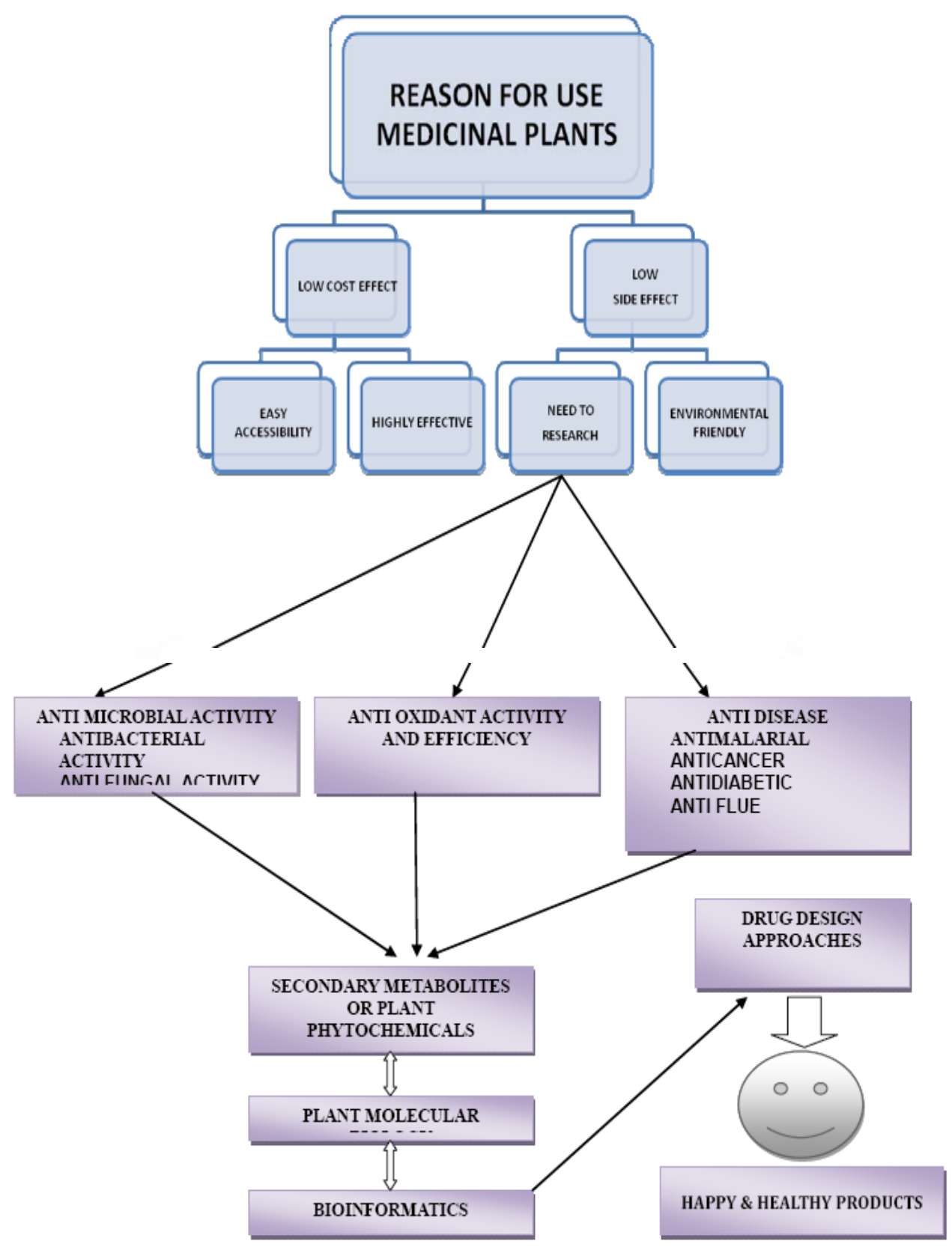

Figure 2. Medicinal plant use and prospects.

\subsubsection{Camptothecin (CPT)}

It is an anticancer and antiviral alkaloid produced by the Chinese tree Camptotheca acuminata (Nyssaceae) and some other species belonging to the families Apocynaceae, Olacaceae, and Rubiaceae. Bark and seeds are currently used as sources for the drug. Several attempts have been made to produce CPT from cell suspensions; however, the low yields obtained limit this approach. Cultures of differentiated cell types may be an alternative source of alkaloid production. Hairy root cultures of $C$. acuminata were established from tissue transformed with Agrobacterium rhizogenes strains ATCC 15834 and R-1000. Integration of these genes are responsible for the hairy-root phenotype ( rol genes) into the plant genome was verified by DNA gel blot analysis. The hairy roots produce and secrete CPT as well as the more potent and less toxic natural derivative, 10 hydroxycamptothecin (HCPT), into the medium. Remarkably, the cultures were able to synthesize the alkaloids at levels equal to, and sometimes greater than, the roots in planta, i.e., 1.0 and $0.15 \mathrm{mg} / \mathrm{g}$ dry weight for CPT and the HCPT, respectively ${ }^{19}$.

\subsubsection{Allium sativum (Garlic)}

Garlice has been used for thousands of years to treat various diseases. The earliest use of Allium sativum as a medicine has been recorded in ancient Egypt, Greece, India, China, Rome, Russia and Europe. Hippocrates was the first to recommend its use for cancer. Allium sativum contains more than 100 biologically useful secondary metabolites, which include alliin, alliinase, allicin, S-allyl-cysteine (SAC), diallyldisulphide (DADS), diallyltrisulphide (DATS) and methylallyltrisuphide. Garlic oil contains an amino acid known as alliin, which is converted to allicin when its 
bulbs are crushed. Allicin is a precursor to several sulphur-containing compounds that are responsible for the flavour, odour and pharmacological properties of Allium sativum. Recent studies revealed presence of bioflavonoids quercetin and cyanidin, which are responsible for antioxidant properties of garlic. Ajoene, a sulphur-containing compound, found in garlic oil, inhibits mutagenesis. Garlic oil prevents prostaglandindependent cancers by inhibiting lipoxygenase and cyclooxygenase enzymes. Garlic contains a rich content of selenium, which is a cellular antioxidant. Diallyltrisulphide, diallyldisulphide and S-allyl-cysteine, found in Allium sativum, have anticarcinogenic properties. Diallyltrisulphide prevents metastases in the lung cancer. Garlic has shown significant therapeutic effect in cancers of the stomach and the intestines. Allium sativum inhibits genesis as well as growth of cancer by enhancing activity of the natural killer cells (NK cells) and the macrophages. Allium sativum also inhibits metastases by preventing adhesion of the circulating cancerous cells to the blood vessels. A Japanese garlic expert, Wakunaga, worked with a German researcher in the Virgin Woodlands of Hokkaido, Japan and prepared a product called "Kyolic Aged Garlic Extract" in 1954 by using 20-month Cold Ageing Process. This ageing process removes toxic compounds and offensive odour of garlic as well as strengthens its therapeutic properties. The Aged Garlic Extract protects DNA from the damaging effect of carcinogens, increases activity of detoxifying enzymes, speeds up excretion of chemical carcinogens and enhances immunity of the body. The Aged Garlic Extract is found to inhibit growth of many cancers including those of the breast, bladder, skin, colon, oesophagus, stomach and the lung. The research done at National Medical Centre and Hospital in Japan has revealed that the Aged Garlic Extract reduces side effects of radiotherapy and chemotherapy ${ }^{20}$

\subsubsection{Ginseng}

Ginseng (Panax ginseng) is traditionally used in some parts of the world as a popular remedy for various diseases including cancer. It was hypothesized that the ginsenoside $\mathrm{Rp} 1$, a component of ginseng, reduces cancer cell proliferation through inhibition of the insulin-like growth factor-1 receptor (IGF-1R)/Akt pathway. Firstly, the efficacy of Rp1 was tested against human breast cancer cell lines. Treatment with Rp1 inhibited breast cancer cell proliferation and inhibited both anchorage dependent and independent breast cancer cell colony formation. In addition, to it the treatment with $20 \mu \mathrm{M} \mathrm{Rp} 1$ induced cycle arrest and apoptosis mediated cell growth suppression. Findings further indicated that Rp1 decreased the stability of the IGF-1R protein in breast cancer cells. Therefore, it is suggest that Rp1 has potential as an anticancer drug and that IGF-1R is an important target for treatment and prevention of breast cancer ${ }^{21}$.

\subsubsection{Tomato}

Tomato (Lycopersicum esculentum) leaves (methanol extract ) on cancer cells to address potential therapeutic in MCF-7breast cancer cell lines and its toxicity towards
Vero cells was shown. The effect of extract towards MCF-7 breast cancer cell lines and Vero cells were observed using in-vitro cytotoxicity assay to indicate its active fractions and its half maximal inhibitory concentration (IC50). Purified sample gave a rational effect towards MCF-7 breast cancer cells with IC50 value of $5.85 \mu \mathrm{g} \mathrm{mL}^{22}$.

\subsubsection{Curcuma longa (Turmeric)}

Contains curcumin, which inhibits the growth of cancer by preventing production of harmful eicosanoid such as PGE-2. The anticancer effect of curcumin has been demonstrated in all the steps of cancer development, i.e. initiation, promotion and progression of cancer. Data obtained from several studies suggest that curcumin inhibits the genesis of cancer as well as promotes the regression of cancer. Curcumin suppresses mutagenic effect of various mutagens including cigarette smoke condensates 7, 12-dimethylbenz (a) anthracene (DMBA) and benzopyrene. Curcumin is found to decrease levels of urinary mutagens. It also possesses anti-inflammatory and antioxidant properties. The protective effects of Curcuma longa and its derivatives are partially due to direct antioxidant effect. Studies have revealed that Curcuma longa inhibits production of nitrosamine that enhances natural antioxidant functions of the body. Curcuma longa increases levels of glutathione and other non-protein sulfhydryls. It acts directly on several enzymes. Curcumin is used to treat squamous cell carcinoma of the skin and the ulcerating oral cancer. Curcuma longa also prevents malignant transformation of leukoplakia ${ }^{23,24}$.

\subsubsection{Gyrophora esculenta}

Gyrophora esculenta (Maitake) is a mushroom that inhibits growth of cancer by enhancing activity of the natural killer cells (NK cells). A study done by Dr. Hiroaki Nanba, Department of Immunology at Kobe Women's 48 College of Pharmacy, Japan has shown that Maitake inhibits carcinogenesis and metastases. Another study conducted at the National Cancer Research Centre in Japan revealed that the extracts of Gyrophora esculenta (Maitake), Lentinus edodes (Shiitake) and Ganoderma lucidum (Reishi) have completely eliminated tumours in 80 per cent cases ${ }^{25}$

\subsubsection{Colchicine}

Colchicine is a plant secondary metabolite extracted from Colchicum autumnale and Gloriosa superba L. It causes mitotic arrest during cell cycle and thus they are considered as potent anti-mitotic drug both in-vitro and in-vivo. Due to severe toxic effects, certain derivatives of colchicine were synthesized namely, 3-demethyl colchicine, colchicoside, thiocolchicocide which showed improved activity against certain leukemic cells and solid tumors 26 .

\subsubsection{Solanum nigrum L. (SNL)}

Solanum nigrum Family-Solanaceae has been traditionally used as a herbal plant, whose fruit is believed to have anti-tumor properties, although the mechanism for the activity remains to be elucidated. An 
ethanol extract from ripe fruits of SNL was prepared and investigated the mechanism involved in its growth inhibitory effect on MCF-7 human breast cancer cells. Results from proliferation assay using tritium uptake showed that the proliferative capacity of MCF-7 cells was strongly suppressed in the presence of SNL ethanol extract. This was further confirmed through MTT assay and trypan blue exclusion experiments, which showed a very close correlation between the SNL extract concentration and the surviving cell numbers. The SNL extract-mediated suppression of cell growth was verified to be apoptotic, based on the appearance of DNA laddering, increase in DNA fragmentation, and low fluorescence intensity in nuclei after propidium iodide staining of the cells. Collectively, findings suggest that SNL fruit extract could be used as an antioxidant and cancer chemo-preventive material ${ }^{27}$.

\subsubsection{Cucurbitacin}

Cucurbitacin, a tetracyclic triterpenoid compound is predominantly obtained from the Cucurbitaceae plants. They possess antiproliferative behaviour against various cancer cell lines. Reports show that Cucurbitacin- I and B selectively inhibit both signal transducer/Janus Kinase 2 (JAK2) activity and activator of transcription-3 (STAT3) pathways. STAT3 is activated in many cancer cell types like prostate cancer, breast cancer and also carcinoma of the head, neck and nasopharynx. Reports show that inhibition of this oncogenic signalling pathway. STAT3 causes tumor cell growth inhibition and leads to apoptosis of cancer cells. Polymeric miscelles are used in delivering this compound because of its water insolubility and non-specific toxicity ${ }^{28,29}$.

\subsubsection{Withania somnifera}

Withania somnifera contains withanolides, which possess immuno- modulatory activity. Withaferin A \& withanolide D found in Withania somnifera are known to inhibit growth of cancer. Studies have revealed that Withania somnifera enhances the therapeutic effect of radiotherapy ${ }^{30}$.

\subsubsection{Ginkgo biloba}

Ginkgo biloba (Yin Guo/ Bai Guo) contains Ginkgolide$\mathrm{B}$, which protects the body against cancer. It inhibits growth of cancer by regulating activity of the plateletactivating factor. A recent study done on the workers of nuclear power station at Chernobyl in Russia has shown that Ginkgo biloba protects the DNA from damaging effects of nuclear radiation ${ }^{31}$.

\subsubsection{Combretastatin A-4}

Combretastatin A-4 is a naturally occurring stilbene compound obtained from the South African bush willow tree, Combretum caffrum Kuntze. This vascular targeting agent disrupts the tubulin structure and the change in morphology of endothelial cells causes deprivation of nutrients to tumor cells by impeding the blood flow through capillaries. Due to its poor solubility, a water-soluble prodrug called Combretastatin A-4 disodium phosphate has been formulated for experimental purpose which is currently under phase II clinical trials ${ }^{32,33}$.

\subsubsection{Irisquinone}

Irisquinone, a benzoquinone with anti-tumor activity is obtained from plant species like Iridaceaelatea pallasii and Iris kumaoensis (Iridaceae). Irisquinone showed good activity against transplantable rodent tumors and also acts as a chemosensitizer 34

\subsubsection{Aloe vera}

Aloe vera contains aloe-emodin, which activates the macrophages to fight cancer. Aloe vera also contains acemannan, which enhances activity of the immune cells against cancer. Aloe vera is found to inhibit metastases

\subsubsection{Camellia sinensis (Green tea)}

Camellia sinensis contains epigallocatechin gallate, which protects against cancer by preventing covalent bonding of carcinogens to the DNA. It also inhibits growth of cancer by eliminating free radicals from the body. Gallates found in green tea protect the body from damaging effects of radiation. A regular use of green tea protects the body against many cancers including those of the liver, oesophagus, stomach, intestine and the lung. Studies have shown that there is lower incidence of stomach cancer in habitual tea drinkers as compared to those, who do not drink tea. It has been observed that daily consumption of 5 grams of green tea inhibits synthesis of nitrosamine (a major carcinogen) in the body ${ }^{36,37}$.

\subsubsection{Berberine}

Berberine, an isoquinoline plant alkaloid is obtained from different plant species including Hvdrastis Canadensis L., (Ranuncufaceae), Berberineeris species (Berberidaceae) and Arcungelisia flaw (Menispermaceae). They showed anti-tumor activity both in-vivo and in-vitro report show that berberine has found effective against osteosarcoma, lung, liver, prostate and breast cancer ${ }^{38,39}$.

\section{CONCLUSION}

This review covers the significant role of natural products used in therapy for various ailments, In the present time Natural products are considered to be symbols of protection in comparison to the synthetic product that are regarded as unsafe to human life and environment. Although a large number of synthetic drugs are being added to the world of present pharmacopoeia, but still no system of medicine in the world has been able to solve all the health problems, which include diseases like Cancer. Plant-derived compounds have played an important role in the development of several clinically useful anti-cancer agents. These include vinblastine, vincristine, the camptothecin derivatives, topotecan and irinotecan, etoposide, derived from epipodophyllotoxin, and paclitaxel. 
Table 1: Some other anticancer Natural Products: $40,28,24,21,10,5$

\begin{tabular}{|c|c|c|c|c|}
\hline Name & Biological source & $\begin{array}{l}\text { Geographical } \\
\text { Source }\end{array}$ & Chemical Constituent & Uses \\
\hline Aconite & $\begin{array}{l}\text { Dried root of } \\
\text { Aconitum napellus, } \\
\text { Ranunculacece } \\
\end{array}$ & $\begin{array}{l}\text { Hungary, } \\
\text { Germany, } \\
\text { Spain Switzerland }\end{array}$ & $\begin{array}{l}\text { Aconitine, hypaconitine, } \\
\text { neopelline, napelline, } \\
\text { neoline }\end{array}$ & $\begin{array}{l}\text { Treatment of } \\
\text { rheumatism, } \\
\text { Inflammation. }\end{array}$ \\
\hline $\begin{array}{l}\text { Allium Sativum } \\
\text { (Garlic) }\end{array}$ & $\begin{array}{l}\text { Bulb of the plant } \\
\text { known as allium } \\
\text { sativum, lilaceae }\end{array}$ & $\begin{array}{l}\text { Central Asia, } \\
\text { southern Europe, } \\
\text { USA and India }\end{array}$ & $\begin{array}{l}\text { Carbohydrate, } \\
\text { protein (albumin), } \\
\text { fat, mucilage }\end{array}$ & $\begin{array}{l}\text { Carminative, } \\
\text { aphrodisiac, } \\
\text { expectorant, } \\
\text { stimulant, disinfectant }\end{array}$ \\
\hline Artemisia & $\begin{array}{l}\text { Unexpanded flower } \\
\text { Heads of Artemisia } \\
\text { cina, Artemisia } \\
\text { buvifolia wall, } \\
\text { Artemisia maritime, } \\
\text { compositae }\end{array}$ & $\begin{array}{l}\text { Pakistan, turkey, } \\
\text { from Kashmir to } \\
\text { kumaon in } \\
\text { Himalayas }\end{array}$ & $\begin{array}{l}\text { Essential oil, } \\
\text { santonin, artemisin }\end{array}$ & Anthelmintic \\
\hline $\begin{array}{l}\text { Camellia } \\
\text { sinensis }\end{array}$ & $\begin{array}{l}\text { Prepared leaves } \\
\text { and leaf buds of } \\
\text { Thea sinensis, } \\
\text { Theaceae }\end{array}$ & $\begin{array}{l}\text { India, Shri lanka., } \\
\text { china, Indonesia, } \\
\text { Japan }\end{array}$ & $\begin{array}{l}\text { Caffeine, theobromine, } \\
\text { theophylline, } \\
\text { gallatonic acid }\end{array}$ & $\begin{array}{l}\text { CNS stimulant, } \\
\text { diuretic }\end{array}$ \\
\hline $\begin{array}{l}\text { Comptotheca } \\
\text { accuminata }\end{array}$ & $\begin{array}{l}\text { Dried stem wood of } \\
\text { comptotheca } \\
\text { acuminate, nyssaceae }\end{array}$ & $\begin{array}{l}\text { China, Tibet, } \\
\text { southern china }\end{array}$ & $\begin{array}{l}\text { Quinoline alkaloid, } \\
\text { camptothecin, } 10 \\
\text { hydroxy camptothecin, } 10 \\
\text { methoxy camptothecin }\end{array}$ & $\begin{array}{l}\text { DNA topoisomerase } \\
\text { Iinhibitors, } \\
\text { antitumour, } \\
\text { antileukemia }\end{array}$ \\
\hline $\begin{array}{l}\text { Catharanthus } \\
\text { roseus }\end{array}$ & $\begin{array}{l}\text { Dried whole plant of } \\
\text { catharanthus } \\
\text { roseus, apocunaceae }\end{array}$ & $\begin{array}{l}\text { South Africa, } \\
\text { India, USA, } \\
\text { Europe, Australia }\end{array}$ & $\begin{array}{l}\text { Vincristine, } \\
\text { vinblastine, } \\
\text { ajmalicine }\end{array}$ & $\begin{array}{l}\text { Antineoplastic, acute } \\
\text { leukemia, hodgkin's } \\
\text { disease }\end{array}$ \\
\hline Curcuma longa & $\begin{array}{l}\text { Dried as well as } \\
\text { fresh rhizome of } \\
\text { the plant known } \\
\text { as curcuma longa, } \\
\text { zingiberaceae }\end{array}$ & $\begin{array}{l}\text { Tamil Nadu, } \\
\text { Andhra Pradesh, } \\
\text { Kerala }\end{array}$ & $\begin{array}{l}\text { Curcuminoids, } \\
\text { curcumin, volatile oil, } \\
\text { starch }\end{array}$ & $\begin{array}{l}\text { Anti inflammatory, } \\
\text { anti arthritic, cervical } \\
\text { cancer }\end{array}$ \\
\hline $\begin{array}{l}\text { Glycyrrhiza } \\
\text { glabra }\end{array}$ & $\begin{array}{l}\text { Dried peeled or } \\
\text { unpeeled root and } \\
\text { stolon of glycyrrhiza } \\
\text { glabra, leguminosae }\end{array}$ & $\begin{array}{l}\text { Spain, Sicily, } \\
\text { England }\end{array}$ & $\begin{array}{l}\text { Glycurrhizin, } \\
\text { glycyrrhizinic acid which } \\
\text { on hydrolysis yield } \\
\text { glycyrrhetinic acid }\end{array}$ & $\begin{array}{l}\text { Expectorant, } \\
\text { demulcent, antigastric } \\
\text { effect }\end{array}$ \\
\hline Panax ginseng & $\begin{array}{l}\text { Dried root of } \\
\text { panax ginseng, } \\
\text { Araliaceae }\end{array}$ & $\begin{array}{l}\text { Korea, china, } \\
\text { Russia, Canada, } \\
\text { USA }\end{array}$ & $\begin{array}{l}\text { Ginsenoisides, } \\
\text { panaxosides, } \\
\text { chikusetsusaponin }\end{array}$ & $\begin{array}{l}\text { Immunomodulatory } \\
\text { drugs }\end{array}$ \\
\hline $\begin{array}{l}\text { Podophyllum } \\
\text { peltatum }\end{array}$ & $\begin{array}{l}\text { Dries rhizomes } \\
\text { and root of } \\
\text { podophyllum } \\
\text { peltatum, } \\
\text { barberidaceae }\end{array}$ & $\begin{array}{l}\text { From Kashmir } \\
\text { to Sikkim and } \\
\text { parts of U.P }\end{array}$ & $\begin{array}{l}\text { Podophyllin, } \\
\text { podophyllotoxin, } \\
\text { alpha and beta peltatins }\end{array}$ & $\begin{array}{l}\text { Cytotoxic action, } \\
\text { treatment of veneral, } \\
\text { purgative }\end{array}$ \\
\hline $\begin{array}{l}\text { Taxus } \\
\text { brevifolia }\end{array}$ & $\begin{array}{l}\text { Dried leaves, } \\
\text { bark and root of } \\
\text { various species of } \\
\text { taxus, taxaceae }\end{array}$ & $\begin{array}{l}\text { India, Canada, } \\
\text { America }\end{array}$ & $\begin{array}{l}\text { Taxane, } \\
\text { cephalomannine, 10- } \\
\text { deacetyl baccatin, taxol }\end{array}$ & $\begin{array}{l}\text { Lung carcinoma, } \\
\text { gastric and cervical } \\
\text { cancers and also } \\
\text { carcinomas of head, } \\
\text { neck, prostate and } \\
\text { colon }\end{array}$ \\
\hline Viola odorata & $\begin{array}{l}\text { Dried aerial parts } \\
\text { obtained from } \\
\text { viola odorata, } \\
\text { violaceae }\end{array}$ & $\begin{array}{l}\text { India (Kashmir) } \\
\text { Pradesh, } \\
\text { Kumaon hills) }\end{array}$ & $\begin{array}{l}\text { Essential oil, } \\
\text { alkaloid, saponins, } \\
\text { Glycoside of methyl } \\
\text { salicylate. }\end{array}$ & $\begin{array}{l}\text { Expectorant, } \\
\text { diaphoretic, } \\
\text { antipyretic, } \\
\text { antibacterial }\end{array}$ \\
\hline Zingiber & $\begin{array}{l}\text { Rhizomes of } \\
\text { zingiber } \\
\text { officinale roscoe, } \\
\text { zingiberaceae }\end{array}$ & $\begin{array}{l}\text { South asia, Africa, } \\
\text { Australia, } \\
\text { Mauritius, Jamaica, } \\
\text { Taiwan, India }\end{array}$ & $\begin{array}{l}\text { Volatile oil, starch, } \\
\text { fat, fibre, inorganic } \\
\text { material, residual } \\
\text { moisture, acrid resinous } \\
\text { matter. }\end{array}$ & $\begin{array}{l}\text { Stomachic, aromatic, } \\
\text { carminative, stimulant, } \\
\text { flavouring agent. }\end{array}$ \\
\hline
\end{tabular}




\section{REFERENCES}

1. Bertram JS, The Molecular Biology of Cancer. Molecular Aspects of Medicine, 2001, 21 (6), 167-223.

2. Nirmala MJ, Samundeeswari A, Sankar PD, Natural plant resources in anti-cancer therapy-A review, Research in Plant Biology, 2011, 1(3), 23-31

3. Sarangi MK, Padhi S, Plants with potential anticancer activities-a Review, International Journal of Phytomedicine, 2014, 6(1), 01 .

4. Dholwani KK, Saluja AK, Gupta AR, Shah DR, A review on plant-derived natural products and their analogs with antitumor activity, Indian journal of pharmacology, 2008, 40(2), 49.

5. Ghersi D, Wilcken N, Simes RJ, A systematic review of taxane-containing regimens for metastatic breast cancer, British journal of cancer, 2005, 93(3), 293-301.

6. Bailey KM, Wojtkowiak JW, Hashim AI, Gillies RJ, Targeting the metabolic microenvironment of tumors, Advances in pharmacology, 2012, 65:63.

7. Nema R, Khare S, Jain P, Pradhan A, Gupta A, Singh D, Natural products potential and scope for modern cancer research, American journal of plant sciences, 2013, 4, 12701277

8. Tsukagoshi S, Hashimoto Y, Fujii G, Kobayashi H, Nomoto K, Orita K. Krestin (Psk), Cancer treatment reviews, 1984, 11(2), 131-55.

9. Agarwal D, Ranawat MS, Chauhan CS, Kamble R, Formulation And Charecterisation Of Colon Targeted $\mathrm{pH}$ Dependent Microspheres Of Capecitabine For Colorectal Cancer, Journal of Drug Delivery and Therapeutics. 2013; 3(6):215-222

10. de Aquino PF, Nunez EL, Sánchez A, Panno R, de Oliveira B, Ayres AF, Nogueira FC, Domont GB, Carvalho PC, Unraveling the gastric cancer proteomic landscape with isobaric markers, America, 2013, 42(2), 261-84.

11. Cragg GM, Newman DJ, Plants as a source of anti-cancer agents, Journal of ethnopharmacology, 2005, 100(1), 72-9.

12. Leveque $\mathrm{D}$, Jehl $\mathrm{F}$, Molecular pharmacokinetics of catharanthus (vinca) alkaloids, The Journal of Clinical Pharmacology, 2007, 47(5), 579-88.

13. Aapro MS, Conte P, Gonzalez EE, Trillet-Lenoir V, Oral vinorelbine, Drugs, 2007, 67(5), 657-67.

14. Yun-San Yip A, Yuen-Yuen Ong E, Chow LW, Vinflunine: clinical perspectives of an emerging anticancer agent, Expert opinion on investigational drugs, 2008,17(4), 583-91.

15. Shoeb M. Montamine, a unique dimeric indole alkaloid, from the seeds of Centaurea Montana (Asteraceae), and its in-vitro cytotoxic activity against the $\mathrm{CaCo} 2$ colon cancer cells, Tetrahedron, 2006, 62, 72-77.

16. Thomson M, Ali M, Current Cancer Drug Targets, 2003, 3(1), 67-81

17. Kingston DGI, The shape of things to come: structural and synthetic studies of taxol and related compounds, Photochemistry, 2007, 68 (14), 1844-1854.

18. Hait WN, Rubin E, Alli E, Goodin S, Tubulin targeting agents, Update on cancer therapeutics, 2007, 2(1), 1-8.

19. Lorence A, Medina-Bolivar F, Nessler CL, Camptothecin and 10-hydroxycamptothecin from Camptotheca acuminata hairy roots, Plant Cell Reports, 2004, 22(6), 437-41.

20. Birbrair A, Zhang T, Wang ZM, Messi ML, Mintz A, Delbono O, Pericytes: multitasking cells in the regeneration of injured, diseased, and aged skeletal muscle, Frontiers in aging neuroscience, 2014, 6:245.

21. Kang JH, Song KH, Woo JK, Park MH, Rhee MH, Choi C, Oh SH, Ginsenoside Rp1 from Panax ginseng exhibits anticancer activity by down-regulation of the IGF-1R/Akt pathway in breast cancer cells, Plant Foods for Human Nutrition, 2011, 66(3):298-305.

22. Chik WW, Amid A, Jamal P, Purification and cytotoxicity assay of tomato (Lycopersicon esculentum) leaves methanol extract as potential anti-cancer agent, Journal of Applied Sciences, 2010, 10(24), 3283-8.
23. Waheed Roomi M, Ivanov V, Kalinovsky T, Niedzwiecki A, Rath M, In vivo and in vitro antitumor effect of a unique nutrient mixture on lung cancer cell line A-549, Experimental lung research, 2006, 32(9), 441-53.

24. Pastore RL, Fratellone P, Potential health benefits of green tea (Camellia sinensis): a narrative review. Explore, 2006, 2(6), 531-9.

25. Hide M, Francis DM, Grattan C, Hakimi J, Kochan JP, Greaves MW, Autoantibodies against the high-affinity $\operatorname{IgE}$ receptor as a cause of histamine release in chronic urticaria, New England Journal of Medicine, 1993, 328(22), 1599-604.

26. Dubey KK, Ray AR, Behera BK, Production of demethylated colchicine through microbial transformation and scale-up process development, Process Biochemistry, 2008, 43(3), 251-7.

27. Son YO, Kim J, Lim JC, Chung Y, Chung GH, Lee JC, Ripe fruits of Solanum nigrum L. inhibits cell growth and induces apoptosis in MCF-7 cells, Food and Chemical Toxicology, 2003, 41(10), 1421-8..

28. Molavi O, Ma Z, Mahmud A, Alshamsan A, Samuel J, Lai R, Kwon GS, Lavasanifar A, Polymeric micelles for the solubilization and delivery of STAT3 inhibitor cucurbitacins in solid tumors, International journal of pharmaceutics, 2008, 347(1), 118-27.

29. Bernard SA, Olayinka OA, Search for a novel antioxidant, anti-inflammatory/analgesic or anti-proliferative drug: Cucurbitacins hold the ace, Journal of Medicinal Plants Research, 2010, 4(25), 2821-6.

30. Lawenda BD, Kelly KM, Ladas EJ, Sagar SM, Vickers A, Blumberg JB, Should supplemental antioxidant administration be avoided during chemotherapy and radiation therapy?, Journal of the national cancer institute, 2008, 100(11), 773-83.

31. Ye B, Aponte M, Dai Y, Li L, Ho MC, Vitonis A, Edwards D, Huang TN, Cramer DW, Ginkgo biloba and ovarian cancer prevention: epidemiological and biological evidence, Cancer letters, 2007, 251(1), 43-52.

32. Thomson P, Naylor MA, Everett SA, Stratford MR, Lewis G, Hill S, Patel KB, Wardman P, Davis PD, Synthesis and biological properties of bioreductively targeted nitrothienyl prodrugs of combretastatin A-4, Molecular cancer therapeutics, 2006, 5(11), 2886-94.

33. Ley CD, Horsman MR, Kristjansen PE, Early effects of combretastatin-A4 disodium phosphate on tumor perfusion and interstitial fluid pressure, Neoplasia, 2007, 9(2), 108-12.

34. Hazra B, Sarma MD, Sanyal U, Separation methods of quinonoid constituents of plants used in Oriental traditional medicines, Journal of Chromatography B, 2004, 812(1), 25975.

35. Xu L, Lao LX, Ge A, Yu S, Li J, Mansky PJ, Chinese herbal medicine for cancer pain, Integrative Cancer Therapies, 2007, 6(3), 208-34.

36. Gonzales GF, Valerio LG, Medicinal plants from Peru: a review of plants as potential agents against cancer, AntiCancer Agents in Medicinal Chemistry, 2006, 6(5), 429-44.

37. $\mathrm{Hu} \mathrm{KW}$, Li QW, Zuo MH, Sun T, Jiang M, Clinical observation on the combined treatment of 57 cases of nonsmall cell lung cancer using argon-helium cryosurgery and Chinese herbal medicine, Chinese journal of integrative medicine, 2007, 13(3), 224-7.

38. Wang F, Gao Y, Gao L, Xing T, Study on the electrochemical behavior of the anticancer herbal drug berberine and its analytical application, Journal of the Chinese Chemical Society, 2011, 58(4), 450-6.

39. Patil JB, Kim J, Jayaprakasha GK, Berberine induces apoptosis in breast cancer cells (MCF-7) through mitochondrial-dependent pathway, European journal of pharmacology, 2010, 645(1), 70-8.

40. Kokate CK., purohit AP, Gokhale SB, Pharmacognosy. $39^{\text {th }}$ ed. Maharashtra: Nirali prakashan; 2007. P. 215, 221, 349, 385, 395, 360, 381, 415, 424, 450, 484, 511, 515, 534. 